a simple diagram to relate the velocities of two molecules before and after a collision makes that plain.

Second, he was not a perfectionist. His algebra, for example, was often spattered with simple errors, unworthy of even a second wrangler. And he was not afraid to publish theories that were manifestly incomplete. Thus Maxwell's equations (published in 1872) were preceded by an attempt to put Faraday's lines of force into mathematical language (in 1861) and by a fanciful model (in 1865) in which the whole of space was occupied by tiny cells capable of carrying charge and rotation (whence the magnetic part of the field). Mahon performs the public service of providing an understandable account of the workings of the tiny cells that were supposed to be the basis of the electromagnetic field.

Third, Maxwell kept worrying away at problems (the kinetic theory and electrodynamics) until their solution had the ring of truth - and then he wrote a book on the subject.

Maxwell's equations were famously found to contain the conclusion that electromagnetic waves travel with the speed of light. Maxwell (and his contemporaries) saw what a breathtaking result that was. Sceptical of action at a distance, the cell-like structure with which he had endowed all space was replaced by the doctrine of the lumeniferous ether.

It seems that Maxwell fell in with the fashion of the day, even to the extent of suggesting in a letter to the director of the US Naval Observatory that the expected 'ether drift' (in which the ether is partly carried along by massive objects such as planets) might be measured by accurate timing of the eclipses of Jupiter's moons. The letter came to light only after Maxwell's death in 1879, aged 48 (see Nature 21,314-315; 1880). Had the data been available during Maxwell's life, there is every chance that he would have anticipated the MichelsonMorley experiment, and that he might have seen the need for special relativity two decades before Einstein. He was that kind of man.

Speculation of this kind belongs, of course, to the disreputable school of the history of what might have been. For Mahon, it is enough that Maxwell paved the way for the revolution to come. Maxwell may have been Mahon's hero for the past 40 years, but his book is not hagiography. General readers will glean from it not merely an absorbing account of Maxwell's life but also an explanation of why his work is at the foundation of the modern world.

John Maddox, now Emeritus Editor, was Editor of Nature for the periods 1966-73 and 1980-95.

\section{Harnessing science for Hitler}

\section{Hitler's Scientists: Science, War and the Devil's Pact}

by John Cornwell

Viking: 2003. 544 pp. £20, \$29.95

\section{Kristie Macrakis}

Adolf Hitler's ignorance about science and its utility during the early years of the Third Reich have become part of legends passed down by scientists and administrators for the next generation. The most-often repeated anecdotes involve Hitler's meetings with Max Planck, Nobel prizewinner and science administrator, and Albert Speer, Hitler's armaments minister. According to Planck, when he tried to persuade Hitler that doing away with Jewish scientists might be harmful, Hitler reportedly dismissed the idea saying: "So we'll do without science for a few years." Even during the Second World War, when leaders had begun to see the utility of science for the war effort, Speer related in his postwar memoirs that the concept of the atomic bomb "strained Hitler's intellectual capacity".

The title of this book implies that
Hitler had a stable of scientists who worked under his direction. This was not the case, but many scientists, physicians and engineers who worked in National Socialist Germany researched areas that supported National Socialist ideology. Others just happened to live and work there. To a certain extent, then, Cornwell distances himself from the Hitler leadership myth and acknowledges the existence of a "polycratic" regime run by competing Nazi institutions such as the army or civil service.

Cornwell, an author and journalist, is known for his best-selling book Hitler's Pope, which is based on archival research. But he admits that Hitler's Scientists is not based on original material. Instead, he has drawn together a history of German science in the first half of the twentieth century, concentrating on the Third Reich from a wide reading of secondary sources.

The time is ripe for this book. Over the past 30 years, historians have unearthed new material and provided fresh interpretations on topics such as Fritz Haber — chemical warfare pioneer, Nobel prizewinner and Jew - racial hygiene, medicine, physics, the German atomic bomb, rocket science and the leading German scientific institution, the

Kaiser Wilhelm Society. But this is the first book to pull these themes together. Cornwell has written an engaging synthesis of the original research: articulate and intelligent, with an eye for telling detail or anecdote. His lively account is also a damning indictment: many scientists come across as depraved, amoral nerds who were willing to serve any regime if they got paid for it. Cornwell unearthed a quotation from Wernher von Braun, designer of the German V-2 'flying bomb' who went on to direct NASA's Apollo programme, illustrating that "he did not care if he worked for Uncle Joe or Uncle Sam: 'All I really wanted was an uncle who was rich'."

Even though much of the book relies on previous work, Cornwell puts his own stamp on the literature and sometimes tells the story better than the specialists. There are also some refreshing new slants: most of the recent academic literature ignores decisively important areas for the war effort such as radar, submarines and codes. Despite his familiarity with the recent literature, which usually provides a more nuanced account of science in the Third Reich than the contemporaneous reports and early postwar histories, Cornwell sometimes reverts back to the tone and interpretation of those earlier accounts. 
The author tasted the flavour of the world's attitude towards the Germans when he was a child growing up in England. He states that an aphorism that echoed through his boyhood and youth was: "The only good German is a dead German." Others saw something "congenitally malevolent about German people". Some of this anti-German attitude has remained in his psyche and surfaces from time to time in the book, even though he engages the newer interpretations. According to Cornwell, no scientist who worked in Nazi Germany is exempt from blame; even an academic scientist working on the purest research is guilty by association. Cornwell, however, wants all scientists to have a conscience, not just those who worked during the Nazi period.

Cornwell extends his period to reflect on the terrorist attacks of 11 September 2001 and technology, and adds material that seems over-detailed and tangential. But like other recent books on science under the Nazis, the real story begins a century earlier. The first quarter of the book describes Germany in the early twentieth century as a scientific mecca, with scientists such as Haber developing poison gas for the fatherland. The science of eugenics, later so important to the Nazis, was also born in this era. Others have written about how science "survived the swastika", but Cornwell emphasizes the strain of the Weimar period, when Germany was under the yoke of the Versailles Treaty and suffered because of the resulting economic problems. Science flourished there nevertheless.

The more sensational topics, such as medical experiments and slave labour, receive the most attention. There is one chapter on sciences that flourished under the Nazis, which includes a summary of Robert Proctor's book The Nazi War on Cancer (Princeton University Press, 1999). But Cornwell ignores the literature that demonstrates that basic biological research also survived and thrived; he thinks it just stagnated. $\mathrm{He}$ also fails to mention the anomaly that three Nobel prizes were awarded to scientists of the Kaiser Wilhelm Society in the 1930s and 1940s for work they did during the Nazi period: Richard Kuhn in 1938 for his work on carotenoids and vitamins; Adolf Butenandt in 1939 for his work on sex hormones; and Otto Hahn in 1944 for his 1938 discovery of nuclear fission. He does, however, add some original research and comments to the controversy surrounding Werner Heisenberg's visit to Niels Bohr in Copenhagen.

Even if Hitler's Scientists is not based on original research and not all scientists belonged to Hitler, it is a useful compilation for readers who would like just one volume on science under the Nazis.

Kristie Macrakis is in the Department of History and the Lyman Briggs School of Science,

Michigan State University, East Lansing,

Michigan 48825, USA.

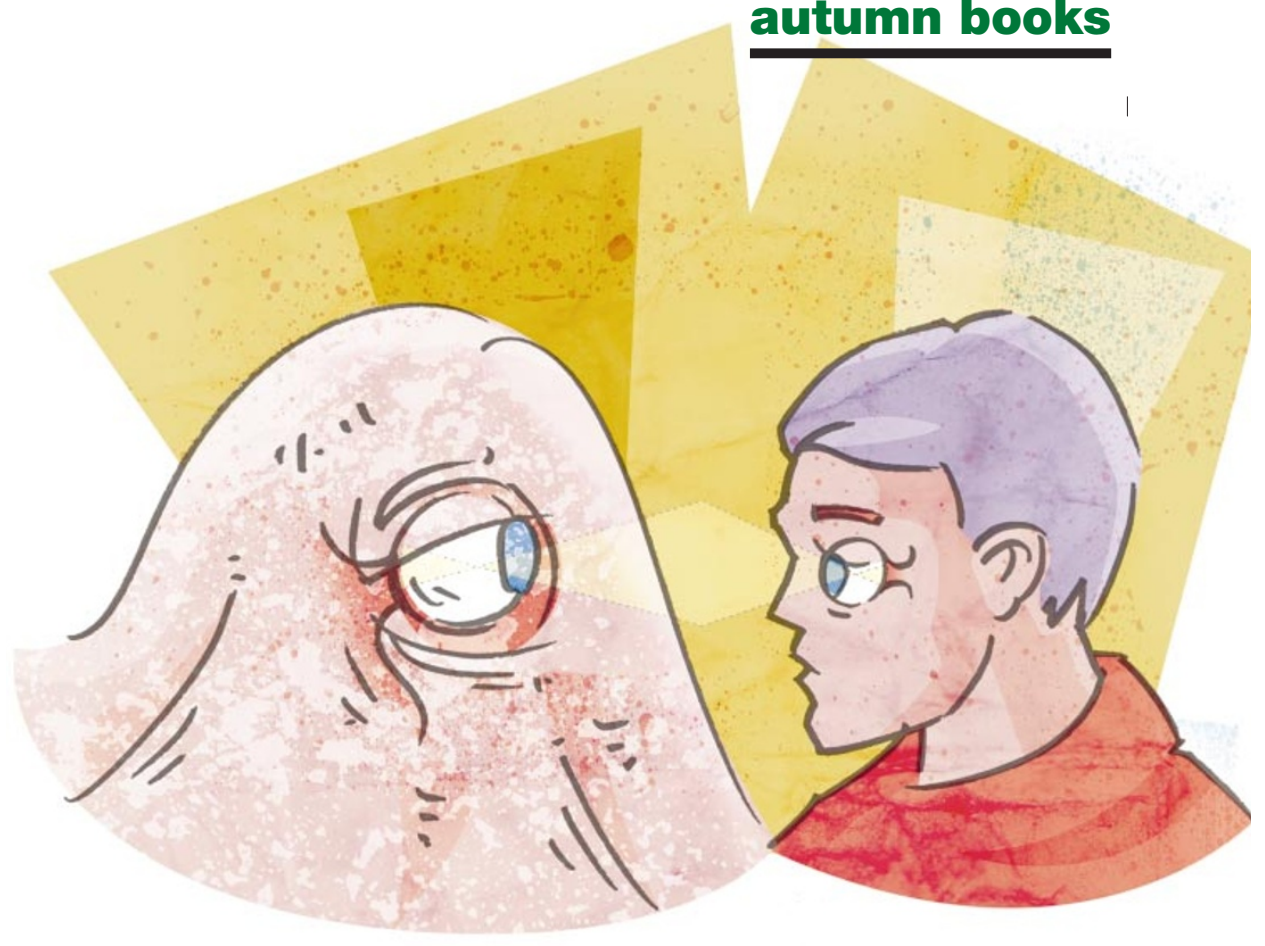

The eyes have it

\section{Life's Solution: Inevitable Humans} in a Lonely Universe

by Simon Conway Morris

Cambridge University Press: 2003. 464 pp.

$£ 18.95, \$ 30$

\section{Richard E. Lenski}

The late Stephen Jay Gould argued that evolution is unpredictable. His thoughtexperiment of replaying life's tape, in Wonderful Life (W. W. Norton, 1989), led him to assert: "Alter any early event, ever so slightly and without apparent importance at the time, and evolution cascades into a radically different channel." The aim of Life's Solution is to overthrow that historically contingent view of life. What is at stake, according to its author Simon Conway Morris, is more than the statistical mechanics of evolution: at stake is how we understand our place in the Universe.

Life's Solution builds a forceful case for the predictability of evolutionary outcomes, not in terms of genetic details but rather their broad phenotypic manifestations. The case rests on a remarkable compilation of examples of convergent evolution, in which two or more lineages have independently evolved similar structures and functions. The examples range from the aerodynamics of hovering moths and hummingbirds to the use of silk by spiders and some insects to capture prey.

Convergence is widespread, despite the infinitude of genetic possibilities, because "the evolutionary routes are many, but the destinations are limited", as Conway Morris puts it. Certain destinations are precluded by "the howling wildernesses of the maladaptive", where the vast majority of genotypes are non-viable and prevent further exploration by natural selection. Conway Morris is spectacularly successful at tracking down and organizing examples of convergent evolution, but he admits that work to place convergences "into any sort of quantitative framework is still in its infancy". In effect, he emphasizes the numerator (convergence) while skirting the denominator (all examples of evolution, both convergent and divergent).

Conway Morris is not content, however, to catalogue examples of convergent evolution. He wants to convince us that convergence implies the inevitability that some sentient human-like being will evolve on any life-bearing planet like Earth. Thus, he focuses his compilation on the attributes we associate with ourselves and the lineage that produced us. Fruiting bodies of slime moulds and myxobacteria show that multicellularity has evolved repeatedly. Warmbloodedness evolved several times, as did live birth and even penile tumescence. Sensory organs exhibit numerous cases of convergence: the eyes have it, as seen in the cameralike eyes of vertebrates and octopuses, and the similar eyes of certain worms and jellyfish. So, too, mechanisms used by diverse organisms to smell, hear, echolocate, sense electrical fields and maintain balance are often convergent.

Complex social systems have evolved repeatedly, exemplified by termites, ants and mole-rats. Fungus-farming ants and tool use by crows remind us that even agriculture and invention have evolved elsewhere. Just as the availability of light to guide organisms has led repeatedly to the evolution of eyes, 